\title{
Industrial Competitiveness and Complementarity between China and Kazakhstan
}

\author{
Yayu Guo \\ ${ }^{1}$ Xidian University, School of Economics and Management, 266 Xinglong Section of Xifeng Road, Xie`an, Shaanxi
}

\begin{abstract}
This paper studies industrial competitiveness and complementarity between China and Kazakhstan under the context of "Silk Road Economic Belt". Competitiveness are studied by the export similarity and the RCA index, and complementarity uses the trade complementary index. It is found that they are not competitive but have their own advantages, Kazakhstan has advantages in resource-intensive industries, while China has advantages in labor-intensive and capital-technology-intensive industries; Complementarity between them is strong, mainly concentrated on the resource-intensive and labor-intensive industries. This paper puts forward some reasons to explain, such as the difference on natural resources, labor and technology.
\end{abstract}

Keywords: industry competitiveness, industry complementarity, reasons of difference

\section{Introduction}

China and Central Asia has a long history on trade, and with the integration of the global economy, trade between the two sides has become more active. On September 7, 2013, Xi Jinping-Chinese President made an important speech in Kazakhstan Nazarbayev University, and proposed to jointly build "Silk Road Economic Belt". It is foreseeable that there will be more economic and trade cooperation between China and Central Asia in the future. As the largest economy among the five Central Asian countries, Kazakhstan has the most trade links with China. Under the new situation of constructing Silk Road Economic Belt, both sides will have more in-depth cooperation. Based on this, this paper studies industrial competitiveness and complementarity between China and Kazakhstan.

\section{Literature Survey}

There is little research on the competitiveness and complementarity of trade between China and Kazakhstan in literature, but the theoretical research on the competitiveness and complementarity of international trade has deeper origins.

From the traditional international trade theory to the new trade theory, it provides the basis for the international trade competitiveness and complementarity. The competitiveness of international trade can be attributed to the theory of comparative advantage, which can be traced back to Adam Smith 's (1776) theory of absolute advantage. David Ricardo (1817) inherited and developed Smith's theory and put forward the theory of comparative advantage. Heckcher and Ohlin (1919) proposed factor endowment theory based on the theory of comparative advantage. Balassa Bela (1965) proposed the revealed comparative advantage (RCA) index which can shows a countryes comparative advantages of an industry, so the previous theory will be reflected with empirical methods ${ }^{[1]}$. For the trade complementarity, there is no systematic theory of trade complementarity in the study of international trade theory, and scholars have proposed an index to measure trade complementarity.

Scholars use the RCA index and the intra-industry trade index to analyze the trade competition and complementarity between China and other countries.

S.M Shafaeddin (2004) used the RCA index to examine whether China is a threat to other developing countries in terms of exports after joining the WTO ${ }^{[2]}$, he believed China had a competitive edge with some developing countries and countries with similar export structures, at the same time, there was a certain degree of trade complementarity, therefore, China ${ }^{e s}$ entry into the WTO would not pose a competitive threat to these countries in a certain period of time, but in the long term, China could get a greater competitive advantage through industrial upgrading.

Yanrui Wu and Zhangyue Zhou (2006) analyzed the current situation and the future development of bilateral trade between China and India through the study in intra-industry trade and comparative advantage of China and India ${ }^{[3]}$, and put forward some policy suggestions to promote the bilateral trade development.

Zude Song and Dongqiang Miao (2008) analyzed the trade structure of China-EU based on the comparative advantage index ${ }^{[4]}$, and concluded that China-EU trade structure was shifting from labor-intensive products to capital-intensive products, and the trade structure was optimized and improved. But it also showed that the industrial competition between China and Europe was also increasing.

Mingyu Jin and Guimin Wang (2011) used the correlation coefficient and the RCA index to examine the trend and characteristics of the comparative advantage model between the three countries based on the changes of the export structure of China, Japan and Korea ${ }^{[5]}$. The calculation showed that the export structure between China and South Korea was more and more similar, the level of division of labor was deepening. The number of products with comparative advantages was decreasing in South Korea, but the expansion of China "e $\mathrm{s}$ exports made the Korean products have a continuous comparative advantage. 


\section{International Journal of Science and Research (IJSR) \\ ISSN (Online): 2319-7064 \\ Index Copernicus Value (2015): 78.96 | Impact Factor (2015): 6.391}

\section{Industrial competitiveness between China and Kazakhstan}

According to the comparative advantage theory, a country will export products with comparative advantages and import inferior products. Therefore, this paper mainly uses the RCA index to calculate the industries number that China and Kazakhstan competing with each other in the world market. The study examines the competitiveness through two aspects: the market similarity and product similarity of all industrial exports of China and Kazakhstan, as well as the industries of the two countries which have comparative advantages in the world at the same time. This paper uses the two-digit classification method which belongs to the Standard International Trade Classification (SITC) to classify goods.

\subsection{Export similarity between China and Kazakhstan}

\subsubsection{Export market similarity between China and Kazakhstan}

The higher the market similarity, the stronger the competition between China and Kazakhstan. In this paper, the quantity of exports from country A to country B accounted for the proportion of country $\mathrm{B}^{\mathrm{ee}} \mathrm{s}$ total exports.is used to measure the status of country A in the country $\mathrm{B}^{\mathrm{ee}}$ s export market.

Table 1 China and Kazakhstan export market rankings in 2012

\begin{tabular}{|c|c|c|c|}
\hline $\begin{array}{c}\text { China's export } \\
\text { market }\end{array}$ & $\begin{array}{c}\text { Kazakhstan's } \\
\text { export market }\end{array}$ & \\
\hline Countries & $\begin{array}{c}\text { Export } \\
\text { proportion (\%) }\end{array}$ & Countries & $\begin{array}{c}\text { Export } \\
\text { proportion (\%) }\end{array}$ \\
\hline United States, & 19 & China & 20 \\
\hline Hong Kong & 11 & Russia & 9.0 \\
\hline Japan & 8.3 & Italy & 8.7 \\
\hline Germany & 4.4 & Netherlands & 7.4 \\
\hline Korea & 3.7 & France & 6.9 \\
\hline United Kingdom & 2.5 & Austria & 4.4 \\
\hline Mexico & 2.4 & Switzerland & 4.1 \\
\hline France & 2.3 & Turkey & 4.0 \\
\hline Russia & 2.3 & Canada & 3.7 \\
\hline India & 2.3 & Romania & 3.5 \\
\hline & & &
\end{tabular}

From Table 1 it can be seen that China ${ }^{\text {ee }}$ top 10 export countries accounted for $58.2 \%$ of total exports, while Kazakhstan accounted for $71.7 \%$, so the top 10 export countries are the main export markets of the two countries to the world, especially for Kazakhstan. There are two same countries, France and Russia, in the top 10 export countries of the two countries. But the two countries in the proportion of the top 10 is not large for China, while the proportion of the two countries has reached $15.9 \%$ in Kazakhstan. It is clear that China and Kazakhstan export market overlap is not high, indicating that the two countries in the export market is not competitive.

\subsubsection{Export products similarity between China and Kazakhstan}

The higher the similarity of export products, the stronger the competition. In this paper, the export volume of a product accounts for the proportion of total exports is used to measure the dominant position of the product in domestic products.
Table 2 China and Kazakhstan export products rankings in

\begin{tabular}{|c|c|c|c|}
\hline China & $\begin{array}{c}\text { Export } \\
\text { proportion } \\
(\%)\end{array}$ & Kazakhstan & \begin{tabular}{|c|} 
Export \\
proportion \\
$(\%)$
\end{tabular} \\
\hline $\begin{array}{c}\text { 77-Electrical } \\
\text { machinery, apparatus } \\
\text { and appliances }\end{array}$ & 14.13 & \begin{tabular}{|c|} 
33-Petroleum, \\
petroleum products \\
and related \\
materials
\end{tabular} & 65.94 \\
\hline $\begin{array}{c}\text { 75-Office machines } \\
\text { and automatic } \\
\text { data-processing } \\
\text { machines } \\
\end{array}$ & 12.56 & $\begin{array}{l}\text { 68-Non-ferrous } \\
\text { metals }\end{array}$ & 7.58 \\
\hline $\begin{array}{l}\text { 76-Telecommunicati } \\
\text { ons and } \\
\text { sound-recording and } \\
\text { reproducing } \\
\text { apparatus and } \\
\text { equipment } \\
\end{array}$ & 12.35 & $\begin{array}{l}\text { 28-Metal ores and } \\
\text { metal scrap }\end{array}$ & 5.41 \\
\hline $\begin{array}{c}\text { 84-Articles of } \\
\text { apparel and clothing } \\
\text { accessories }\end{array}$ & 7.64 & 67-Iron and steel & 4.62 \\
\hline $\begin{array}{c}\text { 89-Miscellaneous } \\
\text { manufactured } \\
\text { articles }\end{array}$ & 7.28 & $\begin{array}{l}\text { 52-Inorganic } \\
\text { chemicals }\end{array}$ & 3.64 \\
\hline $\begin{array}{c}\text { 74-General industrial } \\
\text { machinery }\end{array}$ & 3.9 & $\begin{array}{c}\text { 04-Cereals and } \\
\text { cereal preparations }\end{array}$ & 1.46 \\
\hline $\begin{array}{c}\text { 65-Textile yarn, } \\
\text { fabrics, } \\
\text { made-up articles }\end{array}$ & 3.72 & $\begin{array}{l}\text { 32-Coal, coke and } \\
\text { briquettes }\end{array}$ & 1.29 \\
\hline $\begin{array}{c}\text { 69-Manufactures of } \\
\text { metals }\end{array}$ & 3.68 & $\begin{array}{l}\text { 77-Electrical } \\
\text { machinery, } \\
\text { apparatus and } \\
\text { appliances }\end{array}$ & 0.99 \\
\hline 78-Road vehicles & 2.64 & $\begin{array}{c}\text { 74-General } \\
\text { industrial } \\
\text { machinery } \\
\end{array}$ & 0.78 \\
\hline $\begin{array}{l}\text { 87-Professional, } \\
\text { scientific and } \\
\text { controlling } \\
\text { instruments and } \\
\text { apparatus }\end{array}$ & 2.55 & $\begin{array}{l}\text { 89-Miscellaneous } \\
\text { manufactured } \\
\text { articles }\end{array}$ & 0.61 \\
\hline
\end{tabular}

From Table 2, according to the SITC binary coded classification, it can be seen that there are three same products, 77-Electrical machinery, apparatus and appliances, 74-General industrial machinery, 89-Miscellaneous manufactured articles, in the top 10 export products of the two countries. Although some products overlap, their respective share of the total export volume is very different, we can see the similarity of China and Kazakhstan export products is not high, indicating that the two countries in the export products is not competitive.

\subsection{Revealed comparative advantage}

In order to better compare the industrial competitiveness of China and Kazakhstan, and more specifically to measure the international competitiveness of a segmented industry, revealed comparative advantage index (RCA index) is used to measure the competitiveness of trade products between the two countries. The formula for RCA index is:

$$
R C A=\frac{X_{i k}}{X_{i}} / \frac{W_{k}}{W}
$$

In the formula, $\mathrm{X}_{\mathrm{ik}}$ is the export amount of the k-type products of country $\mathrm{I}, \mathrm{X}_{\mathrm{i}}$ is the total export value of all the products of 


\section{International Journal of Science and Research (IJSR) \\ ISSN (Online): 2319-7064}

Index Copernicus Value (2015): 78.96 | Impact Factor (2015): 6.391

country I, $\mathrm{W}_{\mathrm{k}}$ is the total export value of the k-type products of the world, $\mathrm{W}$ is the total export of all the world ${ }^{\text {ee }}$ s products. From the formula, it can be seen that if the proportion of a product of the country is greater than the proportion of the world, the country has a comparative advantage in the export of the product, at this point, RCA index is greater than 1, on the contrary, the country does not have comparative advantages, RCA index is less than 1; if the RCA index is greater than 2.5 , it indicates that a industry has a very strong international competitiveness; the RCA index between 2.5-1.25, indicating that a industry has a strong international competitiveness; the RCA index between 1.25-0.8, indicating that a industry has a relatively strong international competitiveness; the RCA index less than 0.8 , it indicates that the industry of the country is weak.

\subsubsection{Static analysis on revealed comparative advantage} In order to easily compare, SITC1-SITC4 sector commodity is considered as primary commodity, SITC5-SITC9 sector commodity as industrial products. According to the SITC one digit classification, SITC0-SITC4 primary products are defined as resource-intensive products, SITC6 and SITC8 manufactured goods are defined as labor-intensive products, and SITC5 and SITC7 manufactured goods are defined as capital and technology-intensive products.

Calculating the RCA index of China and Kazakhstan in 2012, it can be seen in Table 3 that China and Kazakhstan industrial competitiveness are as follows:

Table 3 The RCA index of China and Kazakhstan in 2012

\begin{tabular}{|c|c|c|}
\hline SITC code and name & China & Kazakhstan \\
\hline 0-Food and live animals & 0.39 & 0.29 \\
\hline 1-Beverages and tobacco & 0.13 & 0.12 \\
\hline 2-Crude materials, inedible, except fuels & 0.16 & 1.62 \\
\hline $\begin{array}{c}\text { 3-Mineral fuels, lubricants and related } \\
\text { materials }\end{array}$ & 0.03 & 4.24 \\
\hline 4-Animal and vegetable oils, fats and waxes & 0 & 0.02 \\
\hline 5-Chemicals and related products, n.e.s. & 0.50 & 0.37 \\
\hline $\begin{array}{c}\text { 6-Manufactured goods classified chiefly by } \\
\text { material }\end{array}$ & 1.17 & 1.02 \\
\hline $\begin{array}{c}\text { 7-Machinery and transport equipment } \\
\text { 8-Miscellaneous manufactured articles }\end{array}$ & 1.49 & 0.33 \\
\hline $\begin{array}{c}\text { 9-Commodities and transactions not classified } \\
\text { elsewhere in the SITC }\end{array}$ & 0.19 & 0.13 \\
\hline
\end{tabular}

For the resource-intensive products, Kazakhstan ees product competitiveness is significantly stronger than China, China "s RCA index of SITC0-SITC4 sector is not greater than 1, while the RCA index of Crude materials and Mineral fuels in Kazakhstan are greater than 1, with a comparative advantage, even the index of Mineral fuels products is as high as 4.24, demonstrating that this industry has highly international competitiveness. For the labor-intensive products, China $\mathrm{s}$ industrial competitive advantage is significantly higher than Kazakhstan, Chinae"s RCA index of SITC6 and SITC8 sector are greater than 1, the index of SITC8 sector is as high as 2.33, which shows that this industry of China have strong competitiveness. For the capital-technology-intensive products, China ees industrial competitiveness is also stronger than Kazakhstan, especially in Machinery and transport equipment, indicating that China "s technology products has a clear competitive advantage. If industries with the RCA index greater than 1 of both sides are selected as competitive industries, it can be seen that the two countries are not competitive in the resource-intensive and capitaltechnology-intensive industries, and are highly competitive in the labor-intensive industries.

\subsubsection{Dynamic analysis on revealed comparative advantage}

For a countryes dynamic analysis on revealed comparative advantage, scholars have tried to use different indicators to carry out. In order to unify with the former, through the comparison of the RCA index in previous years, the competitiveness of China and Kazakhstan industry is analyzed dynamically. This paper measures the RCA index for 2001, 2005, and 2009, and compared them with the RCA index for 2012.The results are shown in Table 4:

For the resource-intensive products, China ${ }^{\text {ees }}$ industrial advantages showed an overall downward trend, with the RCA index below 1 and still declining. Although the RCA index of Kazakhstan is declining, the index of SITC2 and SITC3 sector products are still above 1, especially in Mineral fuels, the index is still as high as 4.24 , which is very competitive in the international market.

For the labor-intensive industries, China and Kazakhstan both have the comparative advantage on SITC6 sector, the RCA index of China is relatively stable, while Kazakhstan es has dropped from 2.08 to 1.02, from higher than China into lower than China. China has a significant advantage over Kazakhstan in terms of the SITC8 sector. Although the RCA index of China is declining, it is still much higher than that of Kazakhstan, and is also far higher than 1. SITC8 sector belongs to competitive industry in the international market.

For the capital-technology-intensive industries, there is little difference in the RCA index of both sides on SITC5 sector, while the gap is growing on SITC7 sector, Machinery and transport equipment industry of China has been from a competitive advantage into a highly competitive industry, by contrast, Kazakhstan does not have a competitive advantage.

From the above analysis, it is can be seen that the industrial competition between China and Kazakhstan has not changed greatly, and the industrial competitiveness is not strong. Both sides have their own advantages. Kazakhstan has a significant advantage in the resource-intensive industries, while China has a significant advantage in the labor-technology-intensive and the capital-intensive industries.

Table 4 Dynamic analysis on the RCA index of China and Kazakhstan

\begin{tabular}{|c|c|c|c|c|c|c|c|c|}
\hline $\begin{array}{c}\text { SITC code and } \\
\text { name }\end{array}$ & \multicolumn{4}{|c|}{ China } & \multicolumn{4}{|c|}{ Kazakhstan } \\
\cline { 2 - 10 } & 2001 & 2005 & 2009 & 2012 & 2001 & 2005 & 2009 & 2012 \\
\hline $\begin{array}{c}\text { 0-Food and live } \\
\text { animals }\end{array}$ & 0.6 & 0.44 & 0.34 & 0.39 & 0.75 & 0.42 & 0.43 & 0.29 \\
\hline $\begin{array}{c}\text { 1-Beverages and } \\
\text { tobacco }\end{array}$ & 0.25 & 0.18 & 0.15 & 0.13 & 0.35 & 0.19 & 0.14 & 0.12 \\
\hline $\begin{array}{c}\text { 2-Crude materials, } \\
\text { inedible, except } \\
\text { fuels }\end{array}$ & 0.41 & 0.29 & 0.18 & 0.16 & 4.76 & 3.02 & 2.57 & 1.62 \\
\hline $\begin{array}{c}\text { 3-Mineral fuels, } \\
\text { lubricants and } \\
\text { related materials }\end{array}$ & 0.2 & 0.13 & 0.08 & 0.03 & 5.03 & 5.1 & 5.14 & 4.24 \\
\hline
\end{tabular}


International Journal of Science and Research (IJSR)

ISSN (Online): 2319-7064

Index Copernicus Value (2015): 78.96 | Impact Factor (2015): 6.391

\begin{tabular}{|c|c|c|c|c|c|c|c|c|}
\hline $\begin{array}{c}\text { 4-Animal and } \\
\text { vegetable oils, fats } \\
\text { and waxes }\end{array}$ & 0.1 & 0.03 & 0.02 & 0 & 0.06 & 0.05 & 0.01 & 0.02 \\
\hline $\begin{array}{c}\text { 5-Chemicals and } \\
\text { related products, } \\
\text { n.e.s. }\end{array}$ & 0.34 & 0.33 & 0.39 & 0.50 & 0.38 & 0.17 & 0.33 & 0.37 \\
\hline $\begin{array}{c}\text { 6-Manufactured } \\
\text { goods classified } \\
\text { chiefly by material }\end{array}$ & 1.01 & 1 & 1.08 & 1.17 & 2.08 & 1.54 & 1.19 & 1.02 \\
\hline $\begin{array}{c}\text { 7-Machinery and } \\
\text { transport } \\
\text { equipment }\end{array}$ & 0.85 & 1.21 & 1.41 & 1.49 & 0.02 & 0.02 & 0.02 & 0.08 \\
\hline $\begin{array}{c}\text { 8-Miscellaneous } \\
\text { manufactured } \\
\text { articles }\end{array}$ & 3.25 & 2.63 & 2.42 & 2.33 & 0.01 & 0.01 & 0.01 & 0.13 \\
\hline $\begin{array}{c}\text { 9-Commodities } \\
\text { and transactions } \\
\text { not classified } \\
\text { elsewhere in the } \\
\text { SITC }\end{array}$ & 0.15 & 0.15 & 0.2 & 0.19 & 0.15 & 0.19 & 0.17 & 0.22 \\
\hline
\end{tabular}

\section{Industrial complementarity between China and Kazakhstan}

\subsection{Static analysis of industrial complementarity between China and Kazakhstan}

This paper uses Trade complementary Index-Cab to illustrate, the formula is:

$$
\mathrm{C}_{\mathrm{abi}}=\mathrm{RCA}_{\mathrm{ai}} * \mathrm{RCA}_{\mathrm{mbi}}
$$

Where $\mathrm{C}_{\mathrm{abi}}$ is the complementarity index between the two countries, $\mathrm{a}$ and $\mathrm{b}$ are two countries, $\mathrm{i}$ is the trade product, $\mathrm{RCA}_{\mathrm{ai}}$ is the revealed comparative advantage of the i-type products of country a, $\mathrm{RCA}_{\mathrm{mbi}}$ is the revealed comparative disadvantage of the i-type products of country $b$, the formula is:

$$
R C A_{m b i}=\frac{M_{b i}}{M_{b}} / \frac{M_{w i}}{M_{w}}
$$

$\mathrm{M}$ is the import, the numerator is the import of i-type product accounts for the proportion of country $b^{\text {es }}$ s total imports, the denominator is the import of i-type product accounts for the proportion of worldes total imports; the larger the index, the greater the country's revealed comparative disadvantage in the i-type product.

The bigger the $\mathrm{C}_{\mathrm{abi}}$, the stronger the complementarity between $a$ and $b$.
Table 5 The complementarity index of China and Kazakhstan in 2012

\begin{tabular}{|c|c|c|}
\hline SITC code and name & $\begin{array}{c}\text { Advantage of } \\
\text { China and } \\
\text { disadvantage of } \\
\text { Kazakhstan }\end{array}$ & $\begin{array}{c}\text { Advantage of } \\
\text { Kazakhstan and } \\
\text { disadvantage of } \\
\text { China }\end{array}$ \\
\hline 0-Food and live animals & 0.47 & 0.14 \\
\hline 1-Beverages and tobacco & 0.17 & 0.05 \\
\hline $\begin{array}{c}\text { 2-Crude materials, inedible, } \\
\text { except fuels }\end{array}$ & 0.08 & 6.67 \\
\hline $\begin{array}{c}\text { 3-Mineral fuels, lubricants and } \\
\text { related materials }\end{array}$ & 0.01 & 1.69 \\
\hline $\begin{array}{c}\text { 4-Animal and vegetable oils, fats } \\
\text { and waxes }\end{array}$ & 0 & 0.03 \\
\hline $\begin{array}{c}\text { 5-Chemicals and related } \\
\text { products, n.e.s. }\end{array}$ & 0.43 & 0.34 \\
\hline $\begin{array}{c}\text { 6-Manufactured goods classified } \\
\text { chiefly by material }\end{array}$ & 1.90 & 0.79 \\
\hline $\begin{array}{c}\text { 7-Machinery and transport } \\
\text { equipment }\end{array}$ & 1.75 & 0.09 \\
\hline $\begin{array}{c}\text { 8-Miscellaneous manufactured } \\
\text { articles }\end{array}$ & 3.16 & 0.09 \\
\hline $\begin{array}{c}\text { 9-Commodities and transactions } \\
\text { not classified elsewhere in the } \\
\text { SITC }\end{array}$ & 0.05 & 0.30 \\
\hline
\end{tabular}

According to the calculated results, such industries whose $\mathrm{C}$ index is greater than 1 , or $\mathrm{C}$ index is greater than the other country (both countries ${ }^{\text {ee }} \mathrm{C}$ index is greater than 1) can serve as complementary industries with advantages of one country to another. As can be seen from Table 5, the trade complementarity between China and Kazakhstan is generally strong, there are five categories of industries complementary in ten categories of industries, including two categories of resource-intensive industries, one category of labor-intensive industries and two categories of capital-technology-intensive industries. There are three categories of complementary industries with advantages in China to Kazakhstan, including two categories of labor-intensive industries and one category of capital-technology-intensive industries. There are two categories of complementary industries with advantages in Kazakhstan to China, both are resource-intensive industries. The two countries are highly complementary in Crude materials and Miscellaneous manufactured articles, and they belong to resource-intensive industries and labor-intensive industries, it can be seen that the two countries have strong complementarities in these two industries.

\subsection{Dynamic analysis of industrial complementarity between China and Kazakhstan}

This paper studies the changes of industrial complementarity between China and Kazakhstan with the changes of the complementarity index in previous years. It calculates the complementarity index in the years of 2001, 2005, 2009 and 2013, and counts the number of complementary industries and the direction of change of them between China and Kazakhstan. 


\section{International Journal of Science and Research (IJSR) \\ ISSN (Online): 2319-7064}

Index Copernicus Value (2015): 78.96 | Impact Factor (2015): 6.391

Table 6 Dynamic analysis on the complementarity index of China and Kazakhstan

\begin{tabular}{|c|c|c|c|c|c|c|c|c|}
\hline \multirow{2}{*}{$\begin{array}{c}\text { SITC code and name } \\
\text { 2-Food and live animals }\end{array}$} & \multicolumn{3}{|c|}{$\begin{array}{c}\text { Advantage of China and } \\
\text { disadvantage of } \\
\text { Kazakhstan }\end{array}$} & \multicolumn{4}{|c|}{$\begin{array}{c}\text { Advantage of } \\
\text { Kazakhstan and } \\
\text { disadvantage of China }\end{array}$} \\
\cline { 2 - 8 } & 2001 & 2005 & 2009 & 2012 & 2001 & 2005 & 2009 & 2012 \\
\hline 1-Beverages and tobacco & 0.66 & 0.47 & 0.36 & 0.47 & 0.32 & 0.14 & 0.12 & 0.14 \\
\hline 2-Crude materials, inedible, except fuels & 0.29 & 0.23 & 0.19 & 0.17 & 0.08 & 0.03 & 0.03 & 0.05 \\
\hline 3-Mineral fuels, lubricants and related materials & 0.30 & 0.15 & 0.05 & 0.08 & 13.85 & 9.91 & 9.94 & 6.67 \\
\hline 4-Animal and vegetable oils, fats and waxes & 0.26 & 0.11 & 0.05 & 0.01 & 4.03 & 4.06 & 4.67 & 1.69 \\
\hline 5-Chemicals and related products, n.e.s. & 0.24 & 0.03 & 0.02 & 0 & 0.07 & 0.08 & 0.03 & 0.03 \\
\hline 6-Manufactured goods classified chiefly by material & 0.32 & 0.26 & 0.30 & 0.43 & 0.46 & 0.17 & 0.29 & 0.34 \\
\hline 7-Machinery and transport equipment & 1.48 & 1.50 & 2.18 & 1.90 & 2.42 & 1.32 & 0.99 & 0.79 \\
\hline 8-Miscellaneous manufactured articles & 0.87 & 1.42 & 1.57 & 1.75 & 0.03 & 0.03 & 0.02 & 0.09 \\
\hline & 1.67 & 1.4 & 1.22 & 3.16 & 0.01 & 0.01 & 0.01 & 0.09 \\
\hline 9-Commodities and transactions not classified elsewhere in the SITC & 0.01 & 0.05 & 0.01 & 0.05 & 0.05 & 0.04 & 0.02 & 0.30 \\
\hline
\end{tabular}

From Table 6 it can be seen that the complementary industries between China and Kazakhstan increased from four categories to five categories in more than a decade, but the number of complementary industries with advantages is decreasing in Kazakhstan. It shows that Kazakhstan is in a disadvantageous position in complementary cooperation, because its growth of advantageous industries ${ }^{\text {ee }}$ export slower than China.

Kazakhstan has always had a significant advantage in the complementarity of SITC2 sector and SITC3 sector, but the declining $\mathrm{C}$ index also suggests that complementarity is weakening, which is resource-intensive industries. For SITC6 sector, the complementarity index between China and Kazakhstan changes greatly, from Kazakhstan on the advantages of industry into the advantages of industry in China, SITC8 sector has always been the advantageous industries for China to Kazakhstan, which is labor-intensive industries, indicating that there are more and more labor-intensive products exporting from China to Kazakhstan. SITC7 sector is also from not complementary advantageous into complementary advantageous industries from China to Kazakhstan. Combined with the dynamic analysis of the RCA index, this is mainly because of the increase of Chinaes competitive advantage of such industries.

In conclusion, complementary industries between China and Kazakhstan are increasing, indicating that the field of trade cooperation has been widened, and both sides has enhanced the industrial complementarity. But overall the advantageous industries of Kazakhstan is reducing while China's is increasing, the direction of complementarity has changed.

\section{The Reason Analysis of Industrial Competitiveness and Complementarity between China and Kazakhstan}

According to the analysis of industrial competitiveness and complementarity between China and Kazakhstan, there is a obvious gap between the two countries in the industrial competitiveness, and they each have different advantageous industries. Different industrial advantages can be explained by the theory of comparative advantage and factor endowment theory Such as the differences in labor cost and resource endowment between the two countries cause the differences in product cost, resulting in different industrial competitiveness; at the same time, some factors such as the level of technological development and economic development of the two countries also lead to industry complementarity.

\subsection{Difference in natural endowments}

The competitiveness of Kazakhstan "s resource-intensive industries is obviously superior to that of China, mainly due to the differences in natural resources and conditions. Kazakhstan has a large number of oil and gas resources, oil reserves ranked the world's top ten ${ }^{[6]}$, the local government will also make the development of mineral resources as the main task of long-term strategy, oil and gas industries is the main pillar industries. Although China also has rich natural resources, because of the large population, per capita natural resources is not high, so it cannot blindly rely on resource extraction to obtain economic growth.

At present, agriculture and animal husbandry is still the main industry of Kazakhstan, Kazakhstan has a relatively scarce population and ample available arable land, agricultural products not only meet their domestic needs, but also a large number can export to earn foreign exchange, the annual export of grain is about 5 million tons. Kazakhstan has a vast territory and a favorable climate, leading to the country's animal husbandry is also more developed, leather products in the economic and trade cooperation has become a major export industry in Kazakhstan ${ }^{[7]}$. China has no advantage in these industries compared with Kazakhstan, the production of grain is mainly used to meet the basic living needs of the Chinese people because of the large population, in order to guarantee food security, it cannot be exported in large quantities.

\subsection{Difference in labor costs}

Because labor costs are lower than Kazakhstan, China has an advantage in labor-intensive industries. This is mainly due to the oversupply in China's labor market in the long term, leading to lower wages. Low cost leads to an advantage in product price in the labor-intensive industries, making these industrial competitiveness of China stronger. After the reform and opening up, the rapid development of the labor-intensive industries brought by the demographic dividend has made the export of labor-intensive industries the main driving force of China's economic growth. 


\section{International Journal of Science and Research (IJSR) \\ ISSN (Online): 2319-7064}

Index Copernicus Value (2015): 78.96 | Impact Factor (2015): 6.391

While Kazakhstan inherited the former Soviet Union's labor law which is quite sound such as year off and strict eight hour work, 1.5 times the wage will be paid once over and 2 times the wage in holiday, these make labor costs higher. On the other hand, strong labor of Kazakhstan is relatively small, the territorial area is China's $1 / 3$, most of which are better soil, while the population is only 16 million and the social security system is relatively sound, most people do not have high expectations of life, so many people are unwilling to work and labor supply on the labor market is cannot be compared with China ${ }^{[8]}$.

\subsection{Difference in the level of technological development}

China has advantages in capital-technology-intensive industries, this is closely related to the rapid development of economy since the reform and opening-up, more importantly, China promotes the strategy of "invigorating the country through science and education" vigorously. China has also adopted a series of industrial support policies to promote the development of high-tech industries. According to the International Statistical Yearbook, China ${ }^{\text {ee }} \mathrm{R}$ \& D expenditure accounted for $1.8 \%$ of GDP in 2012, higher than the average of $1.2 \%$ in middle-income countries, while Kazakhstan, as a middle-income country, accounted for only $0.2 \%$, the gap is large compared with China ${ }^{[9]}$. For the number of patent applications, the number of resident and non-resident patent applications of China were 535,313 and 11,747 in 2012, while Kazakhstan, respectively, only 1415 and $317^{[10]}$, great disparity. As the independent time is short, the development of science and education in Kazakhstan affected by remaining problem of the former Soviet Union largely, lacking of decision-making authority who can implement unified management and coordination to higher education, a large number of front-line researchers lost due to various reasons during the period of economic transformation, it has had a negative impact on economic development of Kazakhstan. Comparing the two countries, China has obvious advantages.

\section{Conclusion}

Based on the above studies, Kazakhstan has advantages in resource-intensive industries, and China has advantages in capital-technology-intensive industries and labor-intensive industries. The reasons for this difference are the difference of their natural resource endowments, labor cost and technological development levels. The industrial complementarity between the two sides is greater than that of competition, which is very good for the development of industrial cooperation. Moreover, the complementary industries of the two sides are increasing and industry complementarity is also enhanced, which provides favorable conditions to broaden the field of industrial cooperation and carry out deep-seated industrial cooperation in the future.

\section{Future Scope}

The research I have done can be improved from the following aspects in the future: to classify horizontal intra-industry trade and vertical intra-industry trade between China and Kazakhstan; the reasons for industrial competitiveness and complementarity between China and Kazakhstan are complex and require in-depth analysis; use more accurate indicators to measure complementarity and further refine the conclusion that complementarity decreases. The limitations of historical research include that there is little research on the competitiveness and complementarity of trade between China and Kazakhstan in literature, and there is no systematic theory of trade complementarity in the study of international trade theory.

The benefits of historical research include that the theoretical research on the competitiveness and complementarity of international trade has deeper origins. From the traditional international trade theory to the new trade theory, it provides the basis for the international trade competitiveness and complementarity Many scholars use a variety of methods to analyze the trade competition and complementarity between China and other countries, which provides a reference for the study of industrial competition and complementarity between China and Kazakhstan.

\section{References}

[1] Balassa, "Trade Liberation and Revealed Competitive Advantage," The Manchester school of Economic and Social Studies, 33, pp. 92-123, 1965.

[2] S.M Shasaeddin, "Is China "s accession to WTO threatening exports of developing countries," China Economic Review, 15 (2), pp. 109-144, 2004.

[3] Yanrui Wu, Zhangyue Zhou, "Changing bilateral trade between China and India," Journal of Asian Economics, 17 (3), pp. 509-518, 2006.

[4] Zude Song, Dongqiang Miao, “An empirical analysis of trade product structure between China and Europe based on comparative advantage," Chinese Fisheries Economics, 3, pp.81-87, 2008.

[5] Mingyu Jin, Guimin Wang, "The changing characteristics of comparative advantage model in China, Japan and South Korea and its enlightenment," Northeast Asia Forum, 2, 2011.

[6] Yuan Xin, "Oil and gas investment environment in Kazakhstan," Journal of International Economic Cooperation, 8, pp.58-60, 2006.

[7] Yuxin Li, Xinxin Zhu, “An analysis of the prospects of agricultural cooperation between China and Central Asia in the background of "Going Out"," Issues in Agricultural Economy, 9, pp. 42-48, 2010.

[8] Qigang Chen, "Reasearch of the strategy on the regional economic cooperation between China Xinjiang and Kazakhstan," China: Xinjiang Agricultural University, pp.40-48, 2007.

[9] Zhize Zeng, "Technological innovation and industrial structure upgrading," Seminar on sustainable and balanced development strategies in China and South Korea, 2011.

[10] International Statistical Yearbook, China Statistics Press, 2014.

\section{Author Profile}

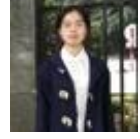

Yayu Guo received the B.S. degree in Economics from Wuhan University of Technology during 2010-2014, now is a master degree candidate of Industrial Economics in Xidian University.

\section{Volume 6 Issue 1, January 2017

